9. Стребков, О. А. Дослідження електромеханічних і теплових перехідних процесів при пуску асинхронних електродвигунів [Текст] / О. А. Стребков // Технологічний аудит та резерви виробництва. - 2015. - № 6/6 (26). - С. 18-25. doi:10.15587/2312-8372.2015.54643

10. Квітка, С. О. Непрямий спосіб вимірювання імпульсу квадрату пускового струму напруги [Текст] / С. О. Квітка, О. Ю. Вовк, О. А. Стребков // Вісник Харківського національного технічного університету сільського господарства імені Петра Василенка. - 2016. - Вип. 175. - С. 91-93.

\section{РАЗРАБОТКА УСТРОЙСТВА, ОБЕСПЕЧИВАЮЩЕГО РЕСУРСОСБЕРЕГАЮЩИЙ ПУСК АСИНХРОННЫХ ЭЛЕКТРОДВИГАТЕЛЕЙ ПРИ ПОНИЖЕННОМ НАПРЯЖЕНИИ}

Представлены результаты аналитического исследования электромеханических и тепловых переходных процессов при пуске асинхронного электродвигателя с короткозамкнутым ротором в условиях пониженного напряжения. В качестве диагностического параметра режима работы электродвигателя в послепусковой период принят импульс квадрата пускового тока. Разработано устройство диагностирования дополнительного теплового износа изоляции асинхронного электродвигателя с короткозамкнутым ротором в послепусковой период.

Ключевые слова: асинхронный электродвигатель, электромеханический и тепловой переходной процесс, пониженное напряжение, пусковой режим.
Вовк Олександр Юрійович, кандидат технічних наук, доцент, кафедра електротехніки і електромеханіки, Таврійський державний агротехнологічний університет, Мелітополь, Украӥна e-mail:aleksvovk020405@yandex.ua, ORCID: http://orcid.org/00000003-0154-6972

Квітка Сергій Олексійович, кандидат технічних наук, доцент кафедра електротехніки і електромеханіки, Таврійський державний агротехнологічний університет, Мелітополь, Украйна e-mail: sergei.kvitka@yandex.ua, ORCID: http://orcid.org/00000001-9234-9274

Нестерчук Діна Миколаївна, кандидат технічних наук, доиент, кафедра електротехніки і електромеханіки, Таврійськии державний агротехнологічний університет, Мелітополь, Україна e-mail: dina-nesterchuk@mail.ru, ORCID: http://orcid.org/00000003-1995-9564

Стребков Олександр Андрійович, асистент, кафедра електротехніки і електромеханіки, Таврійський державний агротехнологічний університет, Мелітополь, Україна, е-таil: sashko@yandex.ru, ORCID: http://orcid.org/0000-0002-8113-7783

Ковальов Олександр Вікторович, стариий викладач, ка федра електротехніки $і$ електромеханіки, Таврійський державний агротехнологічний університет, Мелітополь, Україна, e-mail: aleks_tdaty@mail.ru, ORCID: http://orcid.org/0000-00024646-2919

\section{Trotsenko Ye.,} Brzhezitsky V., Masluchenko I.

\title{
STUDY OF SURGE ARRESTER MODEL UNDER INFLUENCE OF VARIOUS CURRENT PULSES
}

Приведені результати дослідження моделі нелінійного обмежувача перенапруг за допомогою демонстраційної версї Міско-Сар. Визначено залишкову напругу при протіканні крізь нелінійний обмежувач перенапруг як стандартних комутачійних і грозових імпульсів струму різної амплітуди, так і імпульсу струму з крутим фронтом. Показано, що найменша похибка має місце при впливі на модель грозових імпульсів струму.

ключові слова: схемотехнічне моделювання, нелінійний обмежувач перенапруг, залишкова напруга.

\section{Introduction}

Surge arrester is one of the main protective devices, that is used in electrical networks for protection from switching and lightning surges. Due to non-linear resistors based on zinc-oxide materials, the use of surge arresters led to a deeper surge suppression compared with the valve-type arresters based on silicon carbide. The peak value of voltage that appears between the terminals of a surge arrester during the passage of discharge current with given shape and amplitude is called the residual voltage and is one of the most important characteristics of the surge arrester. The residual voltage depends on both the amplitude and the wave shape of the discharge current pulse [1]. For a fixed amplitude of discharge current pulse, the steeper is the front of a current pulse that passes through the surge arrester, the greater is the residual voltage of surge arrester. These and other properties of the surge arresters become important when dealing with the insulation coordination and simulation of lightning protection of substations [2]. There are different models of the surge arrester for circuit simulation software, both simple consisting of a single non-linear element and complex consisting of several linear and non-linear elements. Surge arrester model must recreate in the virtual experiment the behavior of the real device and therefore requires study the influence of the current pulses of various wave shape and amplitude.

\section{The object of research and its technological audit}

The object of the research is the dynamic model of the surge arrester implemented in the evaluation version of Micro-Cap 11 (developed by Spectrum Software Company) and proposed in paper [3]. The duration of lightning and switching surges lies in the microsecond range. In the simulation it is still not sufficiently studied 
the influence of currents typical for both lightning and switching surges. It is possible to study the model of the surge arrester in the above range by comparing the results of computer simulation with the data given in the catalogs of surge arresters. Usually manufacturers publish several values of residual voltage at different current waveforms: at the switching current pulse with the wave shape 30/60 $\mu$ s or $45 / 90 \mu \mathrm{s}$, at the lightning current pulse with the wave shape $8 / 20 \mu \mathrm{s}$, as well as at the steep current pulse with wave shape $1 /(2 \ldots 20) \mu$ s, which can be used in the study.

\section{The aim and objectives of research}

The main aim of the article is to determine the residual voltage of surge arrester model during the passage of discharge current with various shape and amplitude using Micro-Cap circuit simulator. This will allow to assess the error of the surge arrester model separately when it suppresses both switching and lightning overvoltages.

The following objectives were set to reach this aim:

1. Select the surge arrester model for research using Micro-Cap circuit simulation software.

2. Define residual voltage on the surge arrester during the passage of switching discharge currents with wave shape 45/90 $\mu s$, lightning discharge currents with wave shape $8 / 20 \mu s$ and steep current pulse with wave shape $1 / 20 \mu s$ using the Micro-Cap circuit simulator.

3. Compare the residual voltage values obtained in simulation with the appropriate values given in catalogs of surge arresters.

\section{Research of existing solutions of the problem}

Surge arrester model, capable to represent the dynamic behavior of its current-voltage characteristic did not exist until 1992, when such model was developed by working group of the IEEE (Institute of Electrical and Electronics Engineers) Surge protective devices committee and presented in paper [4]. After that three more surge arrester equivalent circuits [5-7] have been proposed, in 1999, 2001 and 2004 respectively. These circuits are in fact the different approaches to improve the surge arrester model proposed in [4]. These four schemes are used to this day, as they allow to simulate the current-voltage characteristic of the surge arrester in the whole range of currents that pass through the device during the suppression both the lightning and switching surges.

In comparison with the other models of surge arrester, the most widely used one is the model [5], which consists of two non-linear resistors, which are connected with each other via two inductive and resistive element. The advantage of this model is that its parameters are determined only based on the data given in the catalogs of surge arrester manufacturing companies [5] and in contrast to the model [4] it does not require the iterative procedure.

The circuit simulation programs are constantly being improved, hence at the overvoltage studies using one or another program the researchers again return to existing surge arrester models and carry out their simulation. Paper [3] was the first to show how to implement the model of the surge arrester [5] in the evaluation version of the Micro-Cap circuit simulator. Papers [4, 8] used two different current pulses in the study of the surge arrester models; [9] - three; [6, 10, 11] - four; [5] - five; [12] eight. In this work, as it will be shown later, we studied the effect of ten different current pulses.

\section{Methods of research}

To achieve objectives that were set such research method was applied: circuit simulation on personal computer. The main materials in this research are the equivalent circuits for the determination of residual voltage on surge arresters terminals.

\section{Research results}

This study is a continuation of the authors' work [3] on the simulation of the surge arrester using the Micro-Cap circuit simulator. The main research circuits are shown on Fig. 1 and represent two equivalent ways of surge arrester simulation using the evaluation version of the Micro-Cap circuit simulator [3].
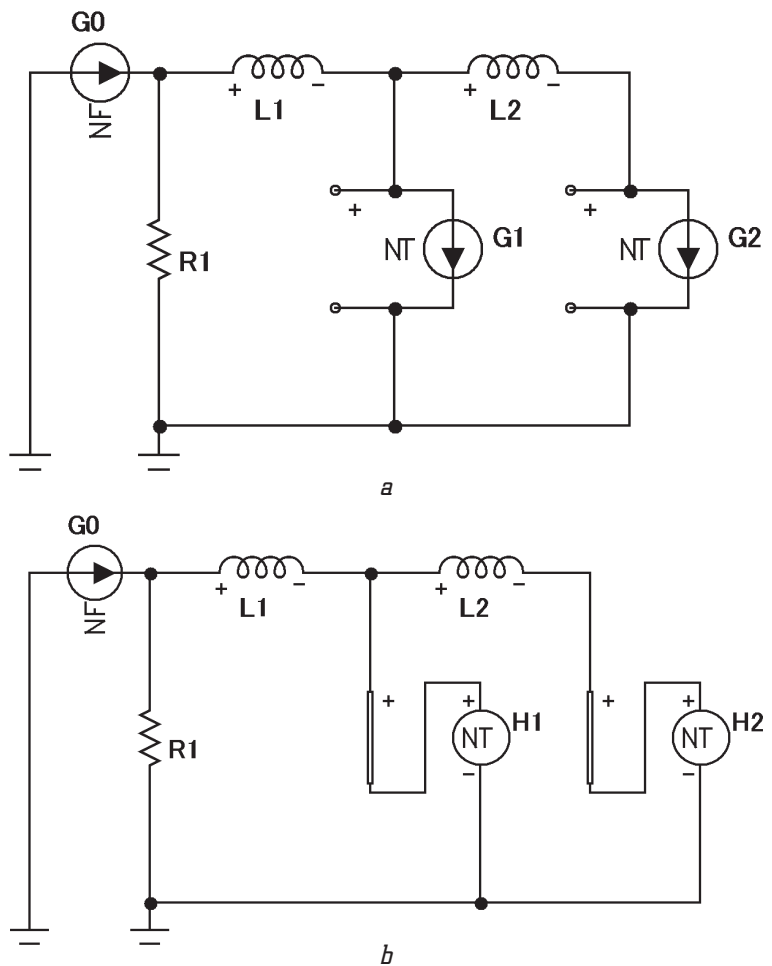

Fig. 1. Surge arrester simulation in Micro-Cap evaluation version: a - voltage-controlled current sources (NTIofV) are used; $b$ - currentcontrolled voltage sources (NTVofI) are used

In Fig. $1 R_{1}, L_{1}$ and $L_{2}$ - linear elements, $G_{1}, G_{2}, H_{1}$ and $H_{2}$ - nonlinear elements of surge arrester model. Resistance $R_{1}$ is $1000 \mathrm{M} \Omega$. In accordance with [5] inductances $L_{1}$ and $L_{2}$ are defined using formula (1) and (2).

$$
\begin{aligned}
& L_{1}=\frac{1}{12} \cdot \frac{V_{r 1 / 20}-V_{r 8 / 20}}{V_{r 8 / 20}} \cdot V_{n}, \\
& L_{2}=\frac{1}{4} \cdot \frac{V_{r 1 / 20}-V_{r 8 / 20}}{V_{r 8 / 20}} \cdot V_{n},
\end{aligned}
$$

where $V_{n}(\mathrm{kV})$ - surge arrester rated voltage; $V_{r 1 / 20}(\mathrm{kV})-$ maximum residual voltage at $10 \mathrm{kA}$ steep current pulse with 
the wave shape $1 / 20 \mu s ; V_{r 8 / 20}(\mathrm{kV})$ - maximum residual voltage at $10 \mathrm{kA}$ lightning current pulse with the wave shape $8 / 20 \mu s$.

Formula (1) and (2) give the value of inductances expressed in $\mu H$ [5].

Functional current source $G_{0}$ in Fig. 1 simulate discharge current pulse passing through the surge arrester. The formula (3) was used to express $45 / 90 \mu s$ current wave, (4) - to express $8 / 20 \mu s$ wave and (5) - to express $1 / 20 \mu s$ wave.

$$
i(t)=\left\{\begin{array}{l}
I_{m} \cdot \sin \left(3.491 \cdot 10^{4} t\right), t \in\left[0, t_{1}\right), \\
I_{m} \cdot \sin \left(2.327 \cdot 10^{4} t+0.524\right), t \in\left[t_{1}, t_{2}\right), \\
0, t \in\left[t_{2}, \infty\right)
\end{array}\right.
$$

where $t_{1}=45 \cdot 10^{-6} \mathrm{sec}, t_{2}=1.125 \cdot 10^{-4} \mathrm{sec}$.

$$
\begin{aligned}
& i(t)=2.18 \cdot I_{m} \cdot e^{-6.510^{4} t} \cdot \sin \left(1.07 \cdot 10^{5} t\right), \\
& i(t)=1.078 \cdot I_{m} \cdot\left(e^{-3.810^{4} t}-e^{-2.6910^{6} t}\right),
\end{aligned}
$$

where $I_{m}(\mathrm{~A})$ - current amplitude.

To allow usage of pulses with negative polarity, or currents that have both positive and negative values (for example, such as (4)), non-linear elements in surge arrester model shown in Fig. 1 according to [3,5] and in accordance with the Micro-Cap syntax [13] must be set, as shown in Table 1, 2 .

In Table 1 and 2 the variable «Vr820» is equal to the residual voltage $V_{r 8 / 20}(\mathrm{~V})$ at the $10 \mathrm{kA}$ current wave with the wave shape $8 / 20 \mu$ s taken from the manufacturer catalog of the surge arrester. It is convenient to specify the value of this variable by means of the «.DEFINE» statement directly on the circuit field in any free place [3, 13].

The simulation results of typical surge arrester with a rated voltage of $108 \mathrm{kV}$ under influence of various current pulses performed with the Micro-Cap circuit simulator are shown in Table 3. Studying the properties of surge arresters of specific manufacturer or several manufacturers is not the aim of this article that is why in the Table 3 the mentioned above surge arrester is presented as the symbol «SA-108». According to the formula (1) and (2) for this surge arrester model: $L_{1}=0.947 \mu \mathrm{H}$ and $L_{2}=2.842 \mu \mathrm{H}$.

\begin{tabular}{|c|c|}
\hline$G_{1}$ & $G_{2}$ \\
\hline$\left(\left\{-1.277^{*} \mathrm{~V}_{г} 820\right\},-20 \mathrm{e} 3\right)$ & $\left(\left\{-1.091 * V_{r} 820\right\},-20 \mathrm{e} 3\right)$ \\
\hline$\left(\left\{-1.195 * V_{r} 820\right\},-10 \mathrm{e} 3\right)$ & $\left(\left\{-1.009 * V_{r} 820\right\},-10 \mathrm{e} 3\right)$ \\
\hline$\left(\left\{-1.108 * V_{г} 820\right\},-3\right.$ е3) & $\left(\left\{-0.922 * V_{г} 820\right\},-3 \mathrm{e} 3\right)$ \\
\hline$\left(\left\{-1.052^{*} \operatorname{Vr}_{\text {r820 }}\right\},-1 \mathrm{e} 3\right)$ & $\left(\left\{-0.866 * \mathrm{~V}_{г} 820\right\},-1 \mathrm{e} 3\right)$ \\
\hline$\left(\left\{-0.974 * 4_{г} 820\right\},-1 \mathrm{e} 2\right)$ & $(\{-0.788 * \operatorname{Vr} 820\},-1 \mathrm{e} 2)$ \\
\hline$\left(\left\{-0.810^{*} V_{\Gamma} 820\right\},-2 \mathrm{e}-3\right)$ & $\left(\left\{-0.623^{*} \mathrm{~V}_{\mathrm{r}} 820\right\},-2 \mathrm{e}-3\right)$ \\
\hline$(0,0)$ & $(0,0)$ \\
\hline$\left(\left\{0.810 * V_{r} 820\right\}, 2 \mathrm{e}-3\right)$ & $\left(\left\{0.623 * V_{r} 820\right\}, 2 \mathrm{e}-3\right)$ \\
\hline$\left(\left\{0.974 * V_{г} 820\right\}, 1 \mathrm{e} 2\right)$ & $\left(\left\{0.788^{*} \mathrm{~V}_{г} 820\right\}, 1 \mathrm{e} 2\right)$ \\
\hline$\left(\left\{1.052^{*} \mathrm{~V}_{\Gamma} 820\right\}, 1 \mathrm{e} 3\right)$ & $\left(\left\{0.866 * V_{г} 820\right\}, 1 \mathrm{e} 3\right)$ \\
\hline$\left(\left\{1.108 * V_{\Gamma} 820\right\}, 3 e 3\right)$ & $\left(\left\{0.922 * V_{r} 820\right\}, 3 e 3\right)$ \\
\hline$\left(\left\{1.195 * V_{г} 820\right\}, 10 \mathrm{e} 3\right)$ & $\left(\left\{1.009 * V_{г} 820\right\}, 10 \mathrm{e} 3\right)$ \\
\hline (\{1.277*汭820\}, 20е3) & $\left(\left\{1.091^{*} \mathrm{~V}_{\Gamma} 820\right\}, 20 \mathrm{e} 3\right)$ \\
\hline
\end{tabular}

Table 1

Non-linear elements of surge arrester model shown in Fig. 1, a

\begin{tabular}{|c|c|}
\hline$H_{1}$ & $H_{2}$ \\
\hline$\left(-20 \mathrm{e} 3,\left\{-1.277^{*} \mathrm{~V}_{\mathrm{r}} 820\right\}\right)$ & $\left(-20 \mathrm{e} 3,\left\{-1.091 * \mathrm{~V}_{\mathrm{V}} 820\right\}\right)$ \\
\hline$\left(-10 \mathrm{e} 3,\left\{-1.195 * \mathrm{~V}_{\mathbf{2}} 820\right\}\right)$ & $\left(-10 \mathrm{e} 3,\left\{-1.009 * \mathrm{~V}_{\mathrm{V}} 820\right\}\right)$ \\
\hline$\left(-3 \mathrm{e} 3,\left\{-1.108 * \mathrm{~V}_{r} 820\right\}\right)$ & $\left(-3 \mathrm{e} 3,\left\{-0.922 * \mathrm{~V}_{r} 820\right\}\right)$ \\
\hline$\left(-1 \mathrm{e} 3,\left\{-1.052 * \mathrm{~V}_{\mathrm{r}} 820\right\}\right)$ & $\left(-1 \mathrm{e} 3,\left\{-0.866 * \mathrm{~V}_{r} 820\right\}\right)$ \\
\hline$\left(-1 \mathrm{e} 2,\left\{-0.974 * V_{r} 820\right\}\right)$ & $\left(-1 \mathrm{e} 2,\left\{-0.788 * \mathrm{~V}_{\mathrm{r}} 820\right\}\right)$ \\
\hline$\left(-2 \mathrm{e}-3,\left\{-0.810^{*} \mathrm{~V}_{\Gamma} 820\right\}\right)$ & $\left(-2 \mathrm{e}-3,\left\{-0.623^{*} \mathrm{~V}_{\Gamma} 820\right\}\right)$ \\
\hline$(0,0)$ & $(0,0)$ \\
\hline$\left(2 \mathrm{e}-3,\left\{0.810^{*} \mathrm{~V}_{\Gamma} 820\right\}\right)$ & $\left(2 \mathrm{e}-3,\left\{0.623^{*} \mathrm{~V}_{\Gamma} 820\right\}\right)$ \\
\hline$\left(1 \mathrm{e} 2,\left\{0.974 * V_{r} 820\right\}\right)$ & $\left(1 \mathrm{e} 2,\left\{0.788 * V_{r} 820\right\}\right)$ \\
\hline$\left(1 \mathrm{e} 3,\left\{1.052 * V_{r} 820\right\}\right)$ & $\left(1 \mathrm{e} 3,\left\{0.866 * \mathrm{~V}_{r} 820\right\}\right)$ \\
\hline (3e3, \{1.108*Vr820\}) & (3e3, \{0.922*Vr820\}) \\
\hline (10e3, $\left.\left\{1.195 * V_{г} 820\right\}\right)$ & (10e3, \{1.009*Vг820\}) \\
\hline (20e3, \{1.277*Vг820\}) & (20e3, \{1.091*Vг820\}) \\
\hline
\end{tabular}

Table 2

Non-linear elements of surge arrester model shown in Fig. 1, b

\begin{tabular}{|c|c|c|c|c|}
\hline \multirow{2}{*}{ No. } & \multirow{2}{*}{$\begin{array}{l}\text { Current pulse (ampli- } \\
\text { tude, wave shape) }\end{array}$} & \multicolumn{2}{|c|}{ Maximum residual voltage, $\mathrm{kV}$} & \multirow{2}{*}{$\begin{array}{l}\text { Relative } \\
\text { error, \% }\end{array}$} \\
\hline & & catalog & simulation & \\
\hline 1 & $0.25 \mathrm{kA}, 45 / 90 \mu s$ & 206.0 & 228.29 & +10.82 \\
\hline 2 & $0.5 \mathrm{kA}, 45 / 90 \mu s$ & 214.0 & 234.29 & +9.48 \\
\hline 3 & $1.0 \mathrm{kA}, 45 / 90 \mu s$ & 223.0 & 246.02 & +10.32 \\
\hline 4 & $2.0 \mathrm{kA}, 45 / 90 \mu s$ & 236.0 & 254.39 & +7.79 \\
\hline 5 & $1.5 \mathrm{kA}, 8 / 20 \mu s$ & 241.0 & 250.56 & +3.97 \\
\hline 6 & $3.0 \mathrm{kA}, 8 / 20 \mu s$ & 254.0 & 262.45 & +3.33 \\
\hline 7 & $5.0 \mathrm{kA}, 8 / 20 \mu s$ & 263.0 & 269.78 & +2.58 \\
\hline 8 & $10.0 \mathrm{kA}, 8 / 20 \mu s$ & 285.0 & 286.33 & +0.47 \\
\hline 9 & $20.0 \mathrm{kA}, 8 / 20 \mu s$ & 316.0 & 307.69 & -2.63 \\
\hline 10 & $10.0 \mathrm{kA}, 1 / 20 \mu s$ & 315.0 & 319.11 & +1.30 \\
\hline
\end{tabular}

Table 3

Residual voltage on "5A-108» at various current pulses

Simulation relative error in Table 3 was determined using the following formula:

$$
\xi=\frac{V_{r T_{1} / T_{2}}^{\prime}-V_{r T_{1} / T_{2}}}{V_{r T_{1} / T_{2}}} \cdot 100, \% \text {. }
$$

In formula (6) $V_{r T_{1} / T_{2}}^{\prime}$ - residual voltage at the passage of current pulse with the wave shape $T_{1} / T_{2} \mu s$ through the surge arrester, received in simulation; $V_{r T_{1} / T_{2}}-$ corresponding value taken from the catalog of surge arresters.

Fig. 2 shows the typical curves of current and voltage received in simulation. The curves corresponding to the rows numbers $1-3$ in Table 3 are similar to the curves in Fig. 2, $a$ and therefore are not presented here. In their turn, the curves corresponding to the rows numbers 5-7 and number 9 in Table 3 are similar to the curves in Fig. 2, $b$ and therefore are also not shown.

Fig. 2 shows that the peak value of residual voltage on the surge arrester terminals always correspondes to the pulse front, as it must be in real applications of surge arrester. Splash in residual voltage growth on the graph (Fig. 2, $c, d$ ) occurs due to the increase of reactance $L_{1} d i / d t$ and $L_{2} d i / d t$ in surge arrester model (Fig. 1) at steep front waves. 

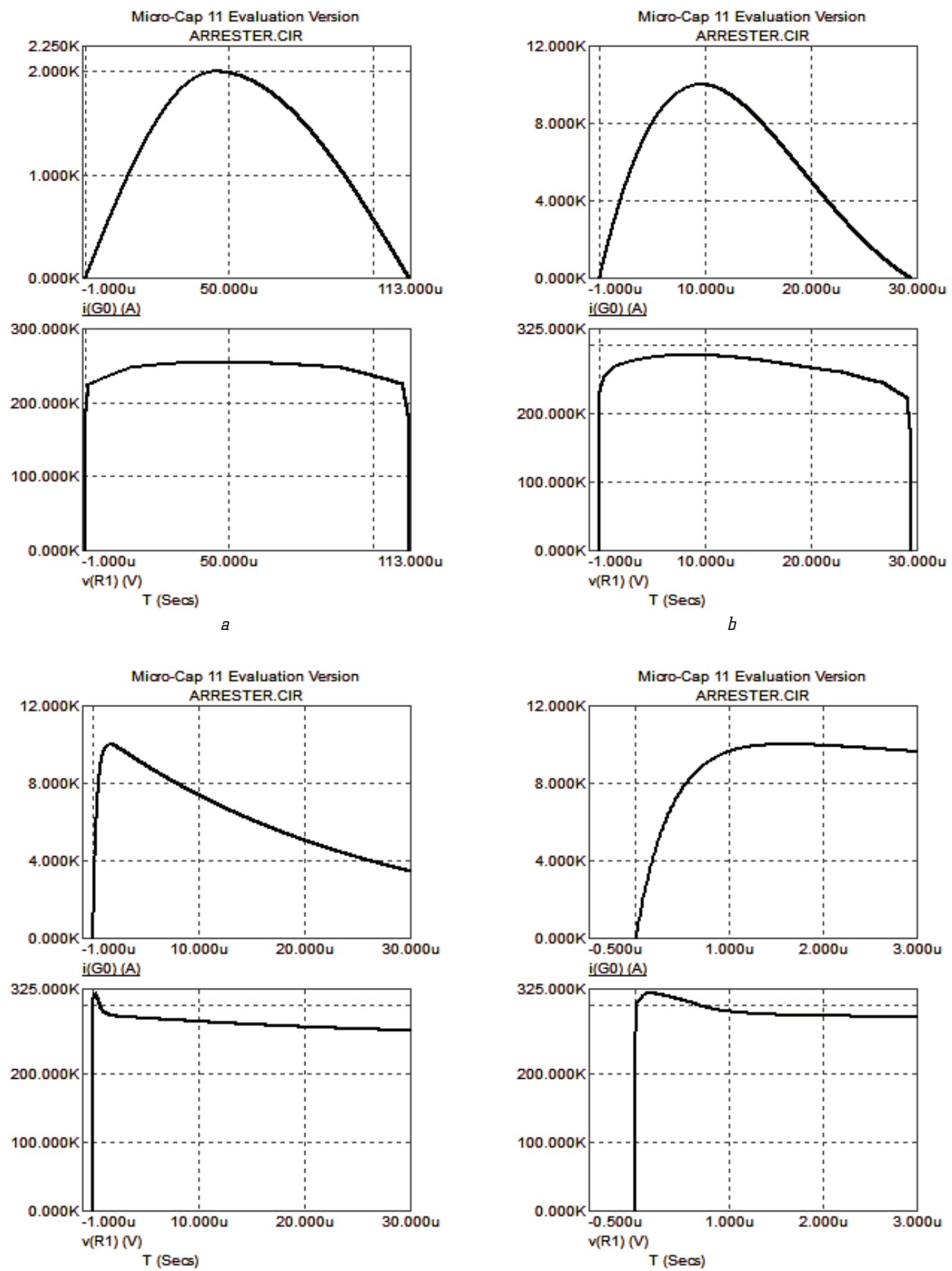

$d$

Fig. 2. Residual voltage (at the bottom) at various current pulses (at the top) passing through the surge arrester: $a-2.0 \mathrm{kA}$ switching current with the wave shape $45 / 90 \mu \mathrm{s} ; b-10.0 \mathrm{kA}$ lightning current with the wave shape $8 / 20 \mu \mathrm{s} ; c-10.0 \mathrm{kA}$ steep front current with the wave shape $1 / 20 \mu \mathrm{s}$; $d-10.0 \mathrm{kA}$ steep front current with the wave shape $1 / 20 \mu \mathrm{s}$ (pulse front area is zoomed)

\section{SWOT-analysis of research results}

Surge arrester model, implemented in the Micro-Cap circuit simulator, allows determine accurately the residual voltage on the surge arrester during the flow of discharge pulses with a rise time of a few microseconds, typical for lightning surges. This strength point enables reliable computing of the lightning overvoltage, which results in damage to the insulation and, thus, causes significant economic loss.
Under switching overvoltage surge arrester model error allows its application only for a rough estimate of the transient amplitude and its progress in time. This weak point can lead to an overestimation of the values of dangerous switching surges, and thus to the overestimation of the level of danger that occurs in the real applications.

The surge arrester model also allows opportunities for the calculation of transients during the flow of the lightning currents composed with several successive pulses, which can pose a significant danger to the surge arresters. 
Threatening point of proposed model: it should not be used for the calculation of the quasi-stationary overvoltage as the surge arresters are not intended to suppress this kind of overvoltage as a result of a lack in energy intensity of varistors.

\section{Conclusions}

1. One of the most widespread dynamic models of the surge arresters offered in [5] was selected for research in the Micro-Cap circuit simulator. Nonlinear elements of the model are referred to the peak value of the residual voltage measured during a passage of $10 \mathrm{kA}$ lightning current pulse with the waveform shape $8 / 20 \mu s$.

2. By means of Micro-Cap circuit simulator the residual voltage on the surge arrester terminals is defined during a passage of the standardized current pulses corresponded to currents at lightning and switching surges.

3. The values of the maximum residual voltage obtained in simulation were compared with corresponding values given by the surge arrester manufacturer. Comparison of results showed that, both at lightning current pulses and at steep front current pulse the lowest error take place when current amplitude is equal to reference value $10 \mathrm{kA}$. With decrease of lightning current amplitude from $10 \mathrm{kA}$ to $1.5 \mathrm{kA}$ the relative error increases, but does not exceed $4 \%$. At switching current pulses the lowest relative error take place when current pulse have the biggest amplitude $2.0 \mathrm{kA}$ and does not exceed $8 \%$. With decrease in amplitude of a switching current pulse to $0.25 \mathrm{kA}$ the relative error increases to approximately $10 \%$. The results of the research can be used to specify the parameters of substation protection against various overvoltages.

\section{References}

1. Brzhezitsky, V. Approximation of volt-ampere characteristics of metal-oxide surge arresters [Text] / V. Brzhezitsky, I. Masluchenko, Ye. Trotsenko, D. Krysenko // Scientific Works of National University of Food Technologies. - 2015. - Vol. 21, № 1. - P. 169-176.

2. Johnnerfelt, B. Coordination of arrester and disconnector characteristics for optimized application of line arresters [Text] / B. Johnnerfelt, Y. K. Tong, C. Sutton, J. L. de Franco // 2013 International Symposium on Lightning Protection (XII SIPDA). 2013. - P. 113-117. doi:10.1109/sipda.2013.6729205

3. Trotsenko, Ye. Surge arrester modeling using Micro-Cap [Text] / Ye. Trotsenko, V. Brzhezitsky, I. Masluchenko // Technology audit and production reserves. - 2016. - № 6/1 (32). - P. 26-30. doi:10.15587/2312-8372.2016.86137

4. Modeling of metal oxide surge arresters [Text] // IEEE Transactions on Power Delivery. - 1992. - Vol. 7, № 1. - P. 302-309. doi:10.1109/61.108922

5. Pinceti, P. A simplified model for zinc oxide surge arresters [Text] / P. Pinceti, M. Giannettoni // IEEE Transactions on Power Delivery. - 1999. - Vol. 14, № 2 - P. 393-398. doi:10.1109/61.754079

6. Fernandez, F. Metal-oxide surge arrester model for fast transient simulations [Text] / F. Fernandez, R. Diaz // IPST'2001 International conference on power system transients. - 2001. P. 144.1-144.5.
7. Magro, M. C. Validation of $\mathrm{ZnO}$ Surge Arresters Model for Overvoltage Studies [Text] / M. C. Magro, M. Giannettoni, P. Pinceti // IEEE Transactions on Power Delivery. - 2004. Vol. 19, № 4. - P. 1692-1695. doi:10.1109/tpwrd.2004.832354

8. Meister, A. Comparison of metal oxide surge arrester models in overvoltage studies [Text] / A. Meister, R. A. Shayani, M. A. G. de Oliveira // International Journal of Engineering, Science and Technology. - 2011. - Vol. 3, № 11. - P. 35-45. doi:10.4314/ijest.v3i11.4s

9. Vita, V. Comparison of metal-oxide surge arresters circuit models and implementation on high-voltage transmission lines of the Hellenic network [Text] / V. Vita, A. D. Mitropoulou, L. Ekonomou, S. Panetsos, I. A. Stathopulos // IET Generation, Transmission \& Distribution. - 2010. - Vol. 4, № 7. P. 846-853. doi:10.1049/iet-gtd.2009.0424

10. Peppas, G. D. Surge arresters models for fast transients [Text] / G. D. Peppas, I. A. Naxakis, C. T. Vitsas, E. C. Pyrgioti // 2012 International Conference on Lightning Protection (ICLP). - 2012. - P. 1-6. doi:10.1109/iclp.2012.6344285

11. Saengsirwan, T. Lightning arrester modeling using ATPEMTP [Text] / T. Saengsirwan, W. Thipprasert // 2004 IEEE Region 10 Conference TENCON 2004. - 2004. - P. 377-380. doi:10.1109/tencon.2004.1414786

12. Miguel, P. M. Comparison of Surge Arrester Models [Text] / P. M. Miguel // IEEE Transactions on Power Delivery. - 2014. Vol. 29, № 1. - P. 21-28. doi:10.1109/tpwrd.2013.2279835

13. Micro-Cap 11. Electronic Circuit Analysis Program. Reference Manual [Electronic resources]. - Sunnyvale, CA: Spectrum Software, 2014. - 1040 p. Available at: \www/URL: http:// www.spectrum-soft.com/down/rm11.pdf

\section{ИССЛЕДОВАНИЕ МОДЕЛИ НЕЛИНЕЙНОГО ОГРАНИЧИТЕЛЯ ПЕРЕНАЛРЯЖЕНИЙ ПРИ ВОЗДЕЙСТВИИ РАЗЛИЧНЫХ ИМПУЛЬСОВ ТОКА}

Приведены результаты исследования модели нелинейного ограничителя перенапряжений с помощью демонстрационной версии Мicro-Сар. Определено остающееся напряжение при протекании сквозь нелинейный ограничитель перенапряжений как стандартных коммутационных и грозовых импульсов тока различной амплитуды, так и импульса тока с крутым фронтом. Показано, что наименьшая погрешность имеет место при воздействии на модель грозовых импульсов тока.

Ключевые слова: схемотехническое моделирование, нелинейный ограничитель перенапряжений, остающееся напряжение.

Trotsenko Yevgeniy, PhD, Associate Professor, Department of High Voltage Engineering And Electrophysics, National Technical University of Ukraine «Igor Sikorsky Kyiv Polytechnic Institute», Kyiv, Ukraine, e-mail:y.trotsenko@kpi.ua, ORCID: http://orcid.org/ 0000-0001-9379-0061

Brzhezitsky Volodymyr, Doctor of Technical Sciences, Professor, Department of High Voltage Engineering And Electrophysics, National Technical University of Ukraine «Igor Sikorsky Kyiv Polytechnic Institute»,Ukraine, e-mail: v.brzhezitsky@kpi.ua, ORCID: http:// orcid.org/0000-0002-9768-7544

Masluchenko Igor, PhD, Associate Professor, Department of High Voltage Engineering And Electrophysics, National Technical University of Ukraine «Igor Sikorsky Kyiv Polytechnic Institute», Ukraine, e-mail: i.masluchenko@kpi.ua,ORCID: http://orcid.org/0000-00016073-9649 